\title{
Anaesthetic Management of a Case of Hereditary Spherocytosis for Splenectomy and Cholecystectomy
}

\author{
A Maaroufi ${ }^{1 *}$, A Diai $^{2}, \mathrm{~N} \mathrm{Jebbar}^{3}, \mathrm{~K}$ Jaber $^{4}, \mathrm{~N} \mathrm{Jbili}^{5}$, L Bibiche $^{6}, \mathrm{~J} \mathrm{Laoutid}^{7}, \mathrm{H}_{\text {Kechna }}{ }^{8}$
}

${ }^{1-4}$ Resident, Military Hospital Moulay Ismail, Meknes, Morocco

${ }_{7}^{5}$, Specialist, Military Hospital Moulay Ismail, Meknes, Morocco

${ }^{7,}$ Associate Professor, Head of the Resuscitation Department, Military Hospital Moulay Ismail, Meknes, Morocco

We could successfully manage the patient with HS posted for laparoscopic splenectomy and cholecystectomy. Perioperative management of HS largely depends on the severity of anaemia and the degree of haemolysis. Anemia should be corrected preoperatively before major surgery. Surgery should be avoided in the presence of haemolytic crisis. Anesthetic challenge includes prevention of hypoxia, acidosis and hypothermia. Vaccination before splenectomy is a must to prevent postoperative infections. Perioperative HS management should include blood transfusions, aggressive hydration, and prevention of hypoxia, acidosis, and temperature regulation $[1,2]$. We report the case of a patient with this disorder presenting for laparoscopic cholecystectomy and splenectomy, under general anesthesia.

Keywords: Hereditary spherocytosis; anesthesia management; splenectomy; cholecystectomy.

Copyright $\left({ }_{0} 2021\right.$ The Author(s): This is an open-access article distributed under the terms of the Creative Commons Attribution 4.0 International License (CC BY-NC 4.0) which permits unrestricted use, distribution, and reproduction in any medium for non-commercial use provided the original author and source are credited.

\section{INTRODUCTION}

Hereditary spherocytosis (HS) is a common cause of non-immune hemolytic anemia due to transmembrane protein abnormalities in RBCs [1]. The case is reported because of the difficulties encountered by the anesthetist due to complications due to 'sickling' based complications. Perioperative HS management should include blood transfusions, aggressive hydration and prevention of hypoxia, acidosis, and temperature regulation [2]. We report the case of a patient with this disorder presenting for laparoscopic cholecystectomy and splenectomy, under general anesthesia.

\section{CASE REPORT}

A 17-year-old girl weighing $48 \mathrm{~kg}$, a known case of HS, was candidate to laparoscopic cholecystectomy and splenectomy. Her mother was splenectomized and a brother treated too for HS. She gave a history of jaundice since she was 4 years old. There were also complaints of abdominal pain and episodes of jaundice for which she had been admitted in the past. On examination, a subictère was seen. His vital signs were stable. Per abdomen examination revealed mild splenomegaly. Rest of the systemic review was unremarkable. A hemogram revealed a hemoglobin level of $9.1 \mathrm{~g} / \mathrm{dL}$, leukocyte and platelet counts within the normal range, a peripheral smear showing typical spherocytes at $3 \%$ with normal mean corpuscular volume (figure 1), a rised reticulocyte count, osmotic fragility tests was normal, proteins electrophoresis showed the persistence of hemoglobin $\mathrm{F}$, prothrombin time, international normalized ratio (INR) was 68\%, and 1.7 respectively. Patient was Rhesus $\mathrm{A}^{+}$. The serum bilirubin level was $2 \mathrm{~g} / \mathrm{dL}$ (unconjugated). Rest of the liver function tests, serum creatinine, and electrolytes were normal. On abdominal ultrasound and scanner, gallstones were present and there was an enlarged spleen (figure 2). The patient was immunized with pneumococcal and Haemophilus influenzae vaccines. 3 units of packed cells, 2 units of FFP were kept ready for an eventual peri-operative transfusion. Patient was premedicated with $\operatorname{Atarax}^{\circledR}$ (hydroxyzine dihydrochloride).

On the morning of surgery, after securing an $18 \mathrm{G}$ intravenous line, an infusion of saline solution was started. Routine monitoring were used (electrocardiogram, pulse oximeter, non-invasive blood pressure cuff and the capnograph was checked). Catheter for epidural analgesia was implanted and then a loading dose of $0.125 \mathrm{mg}$ of bupivacaine was administered. After preoxygenation for 3 minutes, anesthesia was induced with intravenous propofol 3 $\mathrm{mg} / \mathrm{kg}$, fentanyl $5 \gamma / \mathrm{kg}$ and rocuronium $0.6 \mathrm{mg} / \mathrm{kg}$ was used for relaxation. The trachea was intubated with a 
6.5-mm internal diameter cuffed tracheal tube. Anesthesia was maintained with $50 \%$ oxygen in air with isoflurane. IV Fentanyl along with rocuronium were used intraoperatively. End-tidal carbon-dioxide was maintained between 30 and $35 \mathrm{mmHg}$, and intraoperative vitals were stable. Intraoperatively hypoxia, acidosis were avoided. Hypothermia was avoided by infusing hot intravenous fluids and increasing the operating room temperature. Cholecystectomy was done followed by extraction of the spleen through $6 \mathrm{~cm}$ left subcostal incision ("Handassisted laparoscopic splenectomy"). The surgery lasted 1 hour 30 minutes. She received $1 \mathrm{~L}$ of crystalloids during the surgery and her urine output was $120 \mathrm{~mL}$. Blood loss was around $100 \mathrm{ml}$. Patient is extubated once awake with an estimated modified Aldrete score at 10. At the end of surgery, epidural morphine, IV paracetamol and nefopam was given for postoperative analgesia. Postoperative analgesia was multimodal using epidural morphine $5 \mathrm{mg}$ once a day, nefopam and paracetamol if pain. Lovenox 12 hourly was started as thrombo-prophylaxis. From the 1st POD prophylaxis injection Penicillin was also started in addition to other medication. She had a good recovery.

\section{DISCUSSION}

Hereditary spherocytosis is the most frequent hereditary disease of erythrocyte membrane. It results from mutations affecting several sub-membrane proteins (Ankyrin, Spectrin, Band 3, Protein 4.2, Rhesus Complex, Protein 4.1) [3]. Genealogical study shows that $75 \%$ of cases are transmitted in a dominant mode, $25 \%$ in a recessive mode. Hemolysis severity is very variable, and it is often compensated by effective regeneration, explaining the frequency of not very obvious forms. Most pronounced forms seem to result from recessive transmission.

Clinically, anemia is the presenting complaint in nearly half of patients, although the disease severity varies widely among individuals. Mild compensated hemolysis is observed in about $20 \%$ of individuals, with the majority of affected people $(60 \%)$ having moderate haemolysis with a hemoglobin 8-11 g/ dL. The more asymptomatic forms of SH may not be identified until a haemolytic crisis develops during childhood, often triggered by a viral infection. Less commonly, an aplastic crisis develops secondary to parvovirus B19 infection.

The most severe forms of the disease are recessive and associated with $\alpha$-spectrin and some ankyrins defects. The diagnosis is usually supported by examination of red cells on a simple blood smear: excess of spherocytes is usually obvious [4]. Osmotic fragility test is often positive. A recent cytometry technique using labeling with eosin 5'maleimide (EMA) seems to give sensitive and specific results [5]. In difficult cases, ektacytometric study, eventually supplemented by membrane biochemical study, may be necessary. Splenectomy is the only efficient treatment of spherocytosis. It normalizes life of red cells and therefore suppresses any sign of excessive haemolysis. It is not required in each case, especially in clinical latency. Precocious revelation and when the anemia is not compensated, it should be so possible postponed until second infancy or adolescence, because of extreme sensitivity of asplenic children to Streptococcus pneumoniae and Haemophilus b infections so immunisation with their vaccines should precede splenectomy and penicillin prophylaxis would be started whose modalities and duration are not consensual [6;7]. If splenectomy is not indicated, a continuous supply of folic acid is required. If gallstones are present, a cholecystectomy may be performed simultaneously or at a later date. Moreover many patients with such sickling disorder have impairment to oxygen delivery secondary to pulmonary damage, widespread macro and microvasculopathy, increased blood viscosity, anaemia, impaired vascular regulation and disturbed nitric oxide signaling [8].They therefore may have limited reserve to cope with further reduction in oxygen delivery. Thus the avoidance of hypoxaemia is the foundation of anaesthetic management of this patient. The risk of late past spleenectomy thrombosis [9] is also sought out for our patient, and standard thrombo prophylaxis that is subcutaneous heparin was also started.

\section{CONCLUSION}

Peri-operative management of HS depends on the severity of anaemia and the degree of haemolysis. Anesthetic challenge includes prevention of hypoxia, acidosis and hypothermia. Vaccination before splenectomy is a must to prevent postoperative infections.

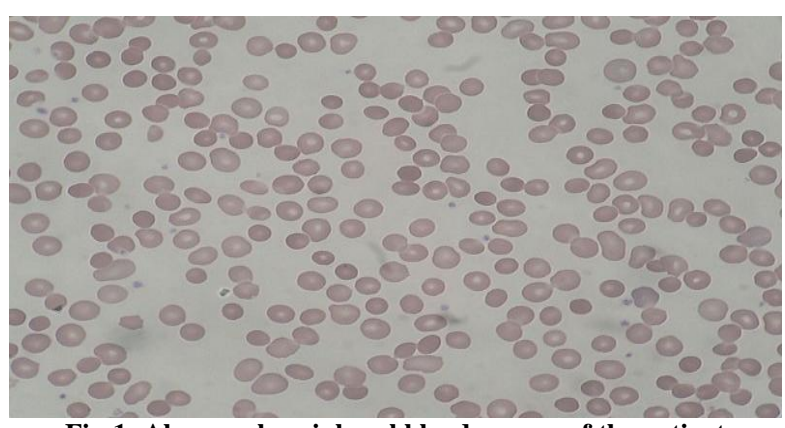

Fig-1: Abnormal peripheral blood smears of the patient

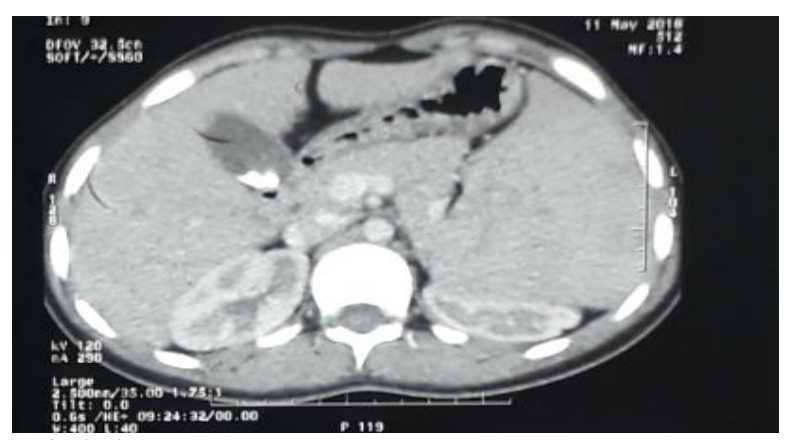

Fig-2: Abdomonal scanner: gallstones and an enlarged spleen 


\section{REFERENCES}

1. Perrotta S, Gallagher PG, and Mohandas N: Hereditary spherocytosis. Lancet. 2008; 372: pp. 1411-1426.

2. A. Shapiro ND, Poe MF. La drépanocytose: un problème

Anesthésiologie. 1955; 16 : 771-80.

3. Perrotta S, Gallagher PG, Mohandas N. Hereditary spherocytosis. The Lancet. 2008 Oct 18;372(9647):1411-26.

4. Jarolim P, Murray JL, Rubin HL, Taylor WM, Prchal JT, Ballas SK, Snyder LM, Chrobak L, Melrose WD, Brabec V, Palek J. Characterization of 13 novel band 3 gene defects in hereditary spherocytosis with band 3 deficiency.

5. King MJ, Behrens J, Rogers C, Flynn C, Greenwood D, Chambers K. Rapid flow cytometric test for the diagnosis of membrane cytoskeletonassociated haemolytic anaemia. British journal of haematology. $2000 \mathrm{Dec} ; 111(3): 924-33$.
6. Mourtzoukou EG, Pappas G, Peppas G, Falagas ME. Vaccination of asplenic or hyposplenic adults. British journal of surgery. 2008 Mar;95(3):273-80.

7. Price VE, Blanchette VS, Ford-Jones EL. The prevention and management of infections in children with asplenia or hyposplenia. Infectious disease clinics of North America. 2007 Sep 1;21(3):697-710.

8. Klinefelter HF. The heart in sickle cell anaemia. Am J Med Sci. 1942; 203:34-51.

9. Eldor A, Rachmilewitz EA. The hypercoagulable state in thalassemia. Blood. 2002; 99: 36-43.

10. Rinder CS. Troubles hématologiques. Dans: Hines RL, Marschall KE, éditeurs. Anesthésie et maladie coexistante. 5ème éd. Pennsylvanie: Elsevier. 2008: 409.

11. Mason R. Troubles médicaux et anesthésiques: sphérocytose héréditaire. Dans: Mason R, éditeur. Recueil de données sur l'anesthésie Manuel périopératoire et péripartum. 3ème éd. Londres: Greenwich Medical Media Ltd. 2001: 245-6. 